\title{
THE ALLIANCES ARRHENATHERION, CYNOSURION AND TRIFOLION MEDII IN WESTERN BULGARIA - ENVIRONMENTAL GRADIENTS AND ECOLOGICAL LIMITATIONS
}

\author{
Nikolay VELEV ${ }^{1}$, Iva APOSTOLOVA ${ }^{1}$, Zuzana ROZBROJOVÁ ${ }^{2,3} \&$ \\ Petra HÁJKOVÁ ${ }^{2,3}$
}

\begin{abstract}
The vegetation of mesic grasslands distributed in the central part of Western Bulgaria is studied. A significant number of 533 relevés were made following the Braun-Blanquet approach. Classification and ordination of the vegetation was performed. The vegetation is classified up to alliance level. The result of the classification are four groups which correspond to the alliances Arrhenatherion elatioris, Cynosurion cristati and Trifolion medii. Within Cynosurion alliance two well distinct subgroups are observed, differing in moisture of the substrate - provisionally called "wet" and "dry" Cynosurion. Ellenberg Indicator Values are used for assessment of ecology of the habitats. The pasture/mowing management of the studied vegetation types is commented.

Key words: Arrhenatherion, Bulgaria, classification, Cynosurion, formal definitions, mesic grasslands, ordination, Trifolion medii.

\section{Izvleček}

Proučevali smo vegetacijo mezofilnih travnikov razširjeno v srednjem delu zahodne Bolgarije. Naredili smo pomembno veliko število (553) popisov po Braun-Blanquetovem pristopu in jih analizirali s klasifikacijo in ordinacijo. Vegetacijo smo nato uvrstili do nivoja zveze. Rezultat klasifikacije so štiri skupine, ki odgovarjajo zvezam Arrhenatherion elatioris, Cynosurion cristati in Trifolion medii. Znotraj zveze Cynosurion smo izločili dve posebni skupini popisov, ki se ločita po vlažnosti tal in ju provizorno imenujemo "vlažni" in "suhi" Cynosurion. Za opis ekologije rastišč smo uporabili Ellenbergove Indikatorske Vrednosti. Komentirali smo tudi gospodarjenje obravnavanih vegetacijskih tipov s košnjo oziroma pašo.

Ključne besede: Arrhenatherion, Bolgarija, klasifikacija, Cynosurion, formalne definicije, mezofilni travniki, ordinacija, Trifolion medii.
\end{abstract}

\section{INTRODUGTION}

The mesic grasslands encompass mostly meadows of high productivity in the lowlands up to the sub-mountain level, that are of significant value for practical and nature conservation purposes. We considered as target vegetation during the field work the content of Arrhenatheretalia elatioris Tüxen 1931 order which according to Ellen- berg (1988) has suboceanic submeridional distribution. In South-Eastern Europe this vegetation type is less frequent as compared to Western $\mathrm{Eu}-$ rope due to limited moisture. Horvat et al. (1974) explain also this limitation with distribution boundaries for many diagnostic species in the region. The diversity of these community types in Central Europe has been well studied (Ellmauer \& Mucina 1993, Dierschke 1995, 1997, Chytrý

\footnotetext{
${ }^{1}$ Institute of Botany, Bulgarian Academy of Sciences, Acad. Georgi Bonchev Street, Bl. 23, 1113 Sofia, Bulgaria, e-mail: nvelev@bio.bas.bg; iva@bio.bas.bg

${ }^{2}$ Institute of Botany, Czech Academy of Sciences, Poříčí 3b, CZ-60300 Brno, Czech Republic

${ }^{3}$ Department of Botany and Zoology, Faculty of Science, Masaryk University, Kotlářská 2, CZ-61137 Brno, Czech Republic, e-mail: zuzkaroz@sci.muni.cz; buriana@sci.muni.cz
} 
2007a, Janišová 2007). For the Balkan Peninsula, a significant amount of information about the vegetation concerned is provided by Horvat et al. (1974), Kojić et al. (1998) and Zelnik (2007). Development and implementation of the recent nature conservation initiatives, namely designation of High Nature Value grasslands (see Veen et al. 2009) requires better knowledge on the species composition, ecological conditions and syntaxonomical diversity of this vegetation.

For the territory of Bulgaria there was no comprehensive information about the diversity of mesic grasslands based on the floristic-ecological studies (see Apostolova \& Slavova 1997). Tzonev et al. (2009) report three associations and one community, assigned to Arrhenatheretalia order, published in the last ten years for the country. The deficiency in the knowledge of Bulgarian meadows has started to be rectified by recent studies on $C y$ nosurion cristati (Dimitrov 2001, 2004; Apostolova \& Meshinev 2006; Pavlov et al. 2006), Arrhenatherion elatioris (Pavlov et al. 2006; Apostolova et al. 2007) and Trifolion medii (Meshinev et al. 2005).

Despite the remarkable progress in implementation of the Braun-Blanquet approach in Bulgaria in the past decade it could be argued that the classification of mesic grasslands is still at the beginning.

The aim of the current study is to establish the high rank syntaxa of the mesic meadows and pastures from the central part of Western Bulgaria, and to provide coherent environmental characteristics for their habitats.

\section{MATERIAL AND METHODS}

\subsection{Study area}

The studied area is situated in the central part of Western Bulgaria (Figure 1). The total observed area is 10796 sq. km., which is approximately a $1 / 10$ part of the territory of the country. According to the climatic division of Bulgaria (Velev 2002) the studied area falls into temperate-continental and transitional-continental regions. The climate in these regions is characterized by warm summers and cold winters and by a high annual amplitude of air temperature. An ombrothermic climatic diagram from Sofia observatory (situated at the centre of the investigated area) is given in Figure 2 according to Lieth et al. (1999). The base rock is mainly silicate.

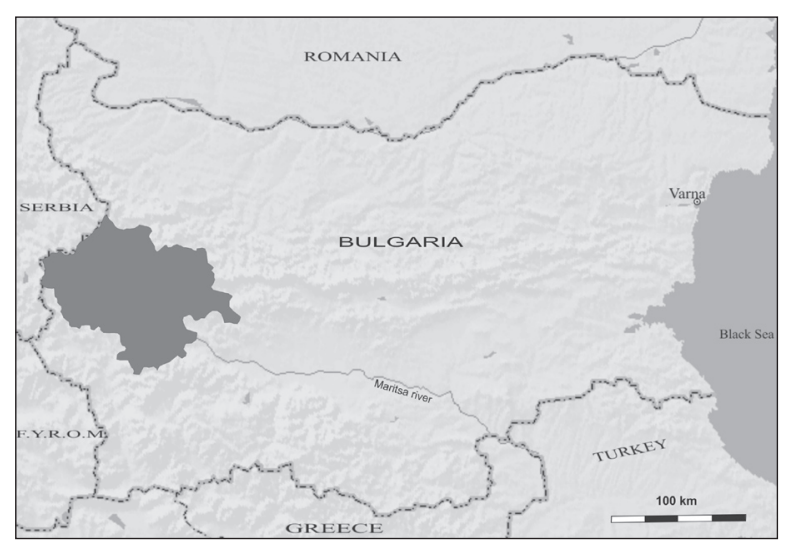

Figure 1: Map of Bulgaria. The studied area is marked in dark gray.

Slika 1: Zemljevid Bolgarije. Obravnavano območje je sivo označeno.

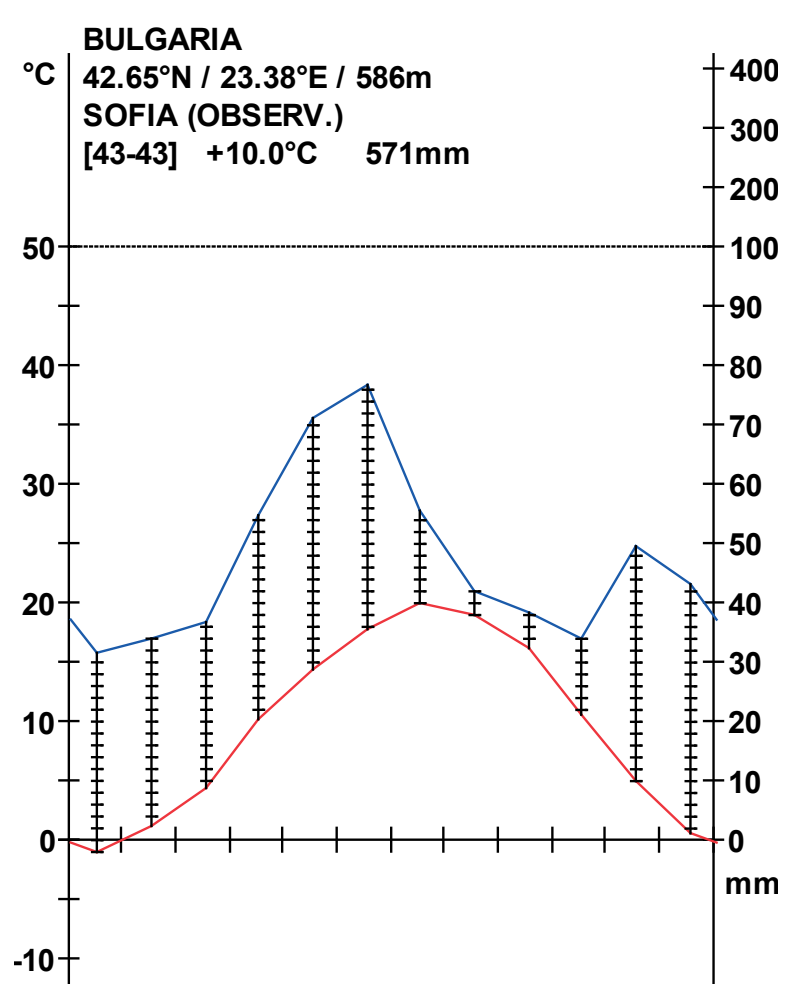

Figure 2: Ombrothermic climatic diagram from the studied area.

Slika 2: Ombrotermični klimatski diagram obravnavanega območja.

\subsection{Field SAMPLing}

The sample plots were set in a manner to cover uniformly the whole area. Altogether 533 relevés within the period 2007-2009 were obtained. During the field sampling we focused on the vegeta- 
tion that ecologically and floristically seemed to belong to Arrhenatheretalia order. The relevés are sampled following the classical approach (BraunBlanquet 1965, Westhoff \& van der Maarel 1973). This relevé type is suitable both for classification and ordination (Whittaker 1973). The form of the sample plots is square with an area of $16 \mathrm{sq}$. metres which is recommended for mesic meadows (Mueller-Dombois \& Ellenberg 1974, Knapp 1984, Kent \& Coker 1992, Chytrý \& Otýpková 2003, van der Maarel 2005, Otýpková \& Chytrý 2006). The sample plots are chosen in the most homogeneous part of the community. Species are estimated by the expanded combined scale for cover/abundance of Braun-Blanquet (Barkman et al. 1964, van der Maarel 1979, Parolly 2003). This scale is a good alternative to the classical (7point) scale of Braun-Blanquet, which is relatively insensitive in the range covered by category "2". The expanded 9-point scale gives greater importance to the abundance (van der Maarel 1979, Parolly 2003).

Soil samples were taken from the depth range of $0-10 \mathrm{~cm}$. Determination of $\mathrm{pH}$ was provided by $\mathrm{pH}$-meter "Jenway 3310 " in $\mathrm{H}_{2} \mathrm{O}$ solution with a soil:water ratio of 1:5, which macerates for at least 18 hours (ISO 10390: Soil quality - Determination of $\mathrm{pH}$ ). After every 10 soil samples the $\mathrm{pH}$-meter was calibrated by HANNA Instruments buffer solutions ( $\mathrm{pH}$ 4.01; $\mathrm{pH}$ 7.01; $\mathrm{pH}$ 10.01).

Pasturemanagementis estimated categorically: 0 - not grazed, 1 - low intensity of grazing, 2 moderate intensity of grazing, 3 - high intensity of grazing. Mowing management is estimated by two categories: 0 - not mown, 1 - mown.

\subsection{DATA PROCESSING}

All the relevés are stored in TURBOVEG database (Hennekens \& Schaminèe 2001). Before conducting any analysis the data were normalized by "square root transformation" (McDonald 2008). The classification was made using the program TWINSPAN (Hill 1979) and is performed within the software package JUICE 7.0 (Tichý 2002, Tichý \& Holt 2006).

Formal definitions were assessed for all alliances using combinations of sociological species groups and species dominance. The sociological groups were generated by the Cocktail method (Bruelheide 1995, 2000) within all relevés and contain species with the highest positive fidelity:
Sociological group Trifolium montanum: Briza media, Chamaespartium sagittale, Danthonia alpina, Helianthemum nummularium, Trifolium montanum;

Sociological groupLeontodonautumnalis:Agrostis capillaris, Anthoxanthum odoratum, Cynosurus cristatus, Holcus lanatus, Leontodon autumnalis;

Sociological group Trisetum flavescens: Medicago lupulina, Trifolium campestre, Trisetum flavescens, Vicia cracca, V. grandiflora.

Delimitation of syntaxa is obtained using the logical operators: AND, OR and NOT. These operators determine which sociological group is to be presented or absent in a relevé, so that the relevé can be referred to the relevant syntaxon (Bruelheide 1997, Chytrý 2007b).

Indirect Gradient Analysis (by Detrended Correspondence Analysis - DCA) using the software product CANOCO 4.5 (ter Braak \& Šmilauer 2002, Lepš \& Šmilauer 2003) is applied.

Environmental conditions in the habitats were assessed using the Ellenberg Indicator Values (EIV) according to Ellenberg et al. (1992). All variables (EIV, total cover, altitude, soil $\mathrm{pH}$ ) are summarized and presented by seven box and whisker plots. The observed differences in variables among the studied vegetation units were tested by one-way ANOVA with Bonferroni (in case of equal variances) and Tamhane (in case of unequal variances) post-hoc tests. The homogeneity (equality) of variance assumption was tested by Levene's test (Levene 1960). A multiple comparison of the summarized variables is revealed in order to show which of them differ statistically significantly among the studied vegetation units. The univariate statistic analyses were performed by SPSS 16.0 software.

The species in the synoptic table (Table 1) are represented by two indicators: Fidelity measure, expressed by the Phi-coefficient (Chytrý et al. 2002) and Constancy, expressed in percentages. The Phi-coefficient values depend on the size of the syntaxa. This problem is avoided by virtual standardizing of the volume of the obtained clusters using the software package JUICE. Phi-coefficient calculated under the standardized database is independent of the actual differences in the volume of any group (Tichý \& Holt 2006). The values of Phi-coefficient are corrected using Fisher's exact test. This is done in order to eliminate the values of Phi-coefficients which are statistically insignificant.

The quality of the classified syntaxa is ex- 
pressed by Sharpness and Uniqueness indexes. A vegetation unit has a high Sharpness index if most of its species are frequent in it, while they are rare or absent in the other clusters in the database. The Uniqueness index searches syntaxa which are unique in a database. It shows whether there are similar vegetation units of the same rank in the dataset. These two indices consider the diagnostic species. The analyses of these indicators express well-defined and poorly defined vegetation units (Chytrý \& Tichý 2003).

Dominant and constant species are listed for every alliance. Species with coverage above $25 \%$ in $5 \%$ of the relevés in any cluster are considered as dominant. Constant species are those having at least $50 \%$ presence in a cluster.

Before determination of formal definitions, dominant and constant species of the two subgroups of Cynosurion alliance were merged into one cluster.

\subsection{Nomenclature}

Taxonomy of the species follows Kozhuharov (1992) and Delipavlov \& Cheshmedjiev (2003). Diagnostic species are selected according to Resmeriţă (1970), Boşcaiu (1971), Dihoru (1975), Lopez (1978), Zuidhoff et al. (1995), Dierschke (1997), Micina (1997), Sanda et al. (1997), Čarni (1997, 2005), Pop et al. (2002), Šeffer et al. (2002), Chytrý \& Tichý (2003), Dutoit (2003), Valachovič (2004), Čarni et al. (2000, 2005), Gandullo \& Faggi (2005), Meshinev et al. (2005), Snowarski (2005), Bărbos (2006), Hájková et al. (2007) and Stančić (2008). Biogeographical affiliation of the species follow Oberdorfer (1994) and for the Balkan endemics Assyov \& Petrova (2006).

\section{RESULTS}

\subsection{Classification AND ORdination}

The TWINSPAN classification and the DCAordination analysis of the relevés distinguished four groups (Table 1, Figure 3) which correspond to the alliances Trifolion medii, Cynosurion cristati with two well delimited subgroups with respect to the soil moisture provisionally called "dry" and "wet" type and Arrhenatherion elatioris.

The largest number of relevés is confined to the Arrhenatherion elatioris. Although species di- versity per sample plot is lowest (36) as compared to the other studied groups, the total species sampled within this alliance numbers 411. Arrhenatherion alliance is defined by a very low Sharpness index (9.14), which is a result of many generalist species presented. Similar could be stated for the "dry" Cynosurion which has a Sharpness index of 3.78. On the other hand the "wet" Cynosurion includes species which are not presented in the rest of the data, and the Uniqueness index has the highest value of 42 within the studied samples.

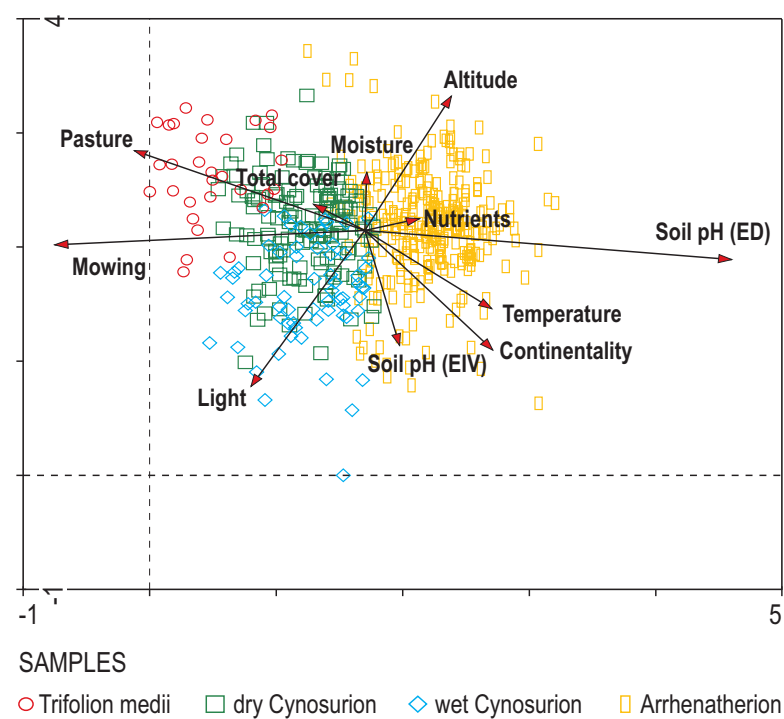

ENV. VARIABLES

Figure 3: Indirect gradient analysis. Biplot diagram of DCA. The main axes correlate with the gradients of moisture and soil reaction. ED - Empirical Data, EIV - Ellenberg Indicator Values.

Slika 3: Indirektna gradientna analiza. DCA dvorazsežnostni diagram. Glavni osi z gradientoma vlažnosti in reakcije tal. ED - empirični podatki, EIV - Ellenbergove Indikatorske Vrednosti.

\subsection{ECOLOGIGAL DIFFERENCES AMONG ALLIANCES}

Trifolion medii occupies habitats with most dry soils, the lowest values of $\mathrm{pH}$ and with a minimum of nutrients (Figure 5). This alliance shows a resemblance to "dry" Cynosurion. The latter, in turn, shows the least expressed specifics for environmental factors in comparison with the other three vegetation units. The wettest sites are occupied by the "wet" Cynosurion. Arrhenatherion alliance is well distinguished by many variables compared to the other vegetation units (Table 3 ). 
Its habitats are located at lowest altitudes and are characterized by their highest values of temperature and soil pH (Figure 5).

\subsection{DESGRIPTION OF PARTICULAR ALLIANCES}

In order to present the characteristics of the obtained alliances in the studied area a short description is provided for each of them:

Trifolio-Geranietea Müller 1962

Origanetalia vulgaris Müller 1962

Trifolion medii Müller 1962

Diagnostic species: Centaurea jacea, Trifolium medium, T. montanum.

Constant species: Achillea millefolium, Agrostis capillaris, Anthoxanthum odoratum, Briza media, Chamaespartium sagittale, Danthonia alpina, Festuca nigrescens, F. valesiaca, Filipendula vulgaris, Galium verum, Leontodon hispidus, Lotus corniculatus, Plantago lanceolata, Rumex acetosa, Stellaria graminea.

Dominant species: Danthonia alpina.

Formal definition: Group Trifolium montanum NOT Group Leontodon autumnalis.

Soil pH optimum: medium acidic (5.4-6.0).

Altitude range: $798-1242 \mathrm{~m}$.

Base rock: silicate.

This is the best separated alliance in our database. The Sharpness index (24.08) and the

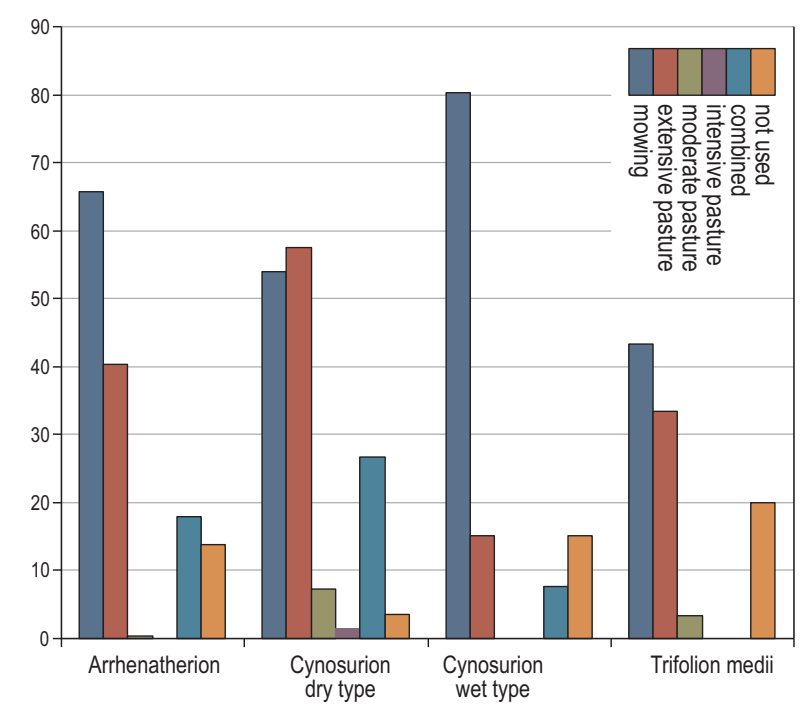

Figure 4:. The mowing/grazing management of the studied vegetation types.

Slika 4: Gospodarjenje (paša/košnja) s proučevanimi vegetacijskimi tipi.
Uniqueness index (38.80) values prove its distinctness within the data set. It contains a relatively small number of relevés but the species diversity is high - total species number is 220 and average species per relevé is 39 (Table 2). The vegetation is used for hay-making and pasturing (Figure 4).

\section{Molinio-Arrhenatheretea Tüxen 1937}

Arrhenatheretalia elatioris Tüxen 1931

Cynosurion cristati Tüxen 1947

Diagnostic species: Agrostis capillaris, Anthoxanthum odoratum, Cichorium intybus, Cynosurus cristatus, Leontodon autumnalis.

Constant species: Achillea millefolium, Agrostis capillaris, Anthoxanthum odoratum, Alopecurus pratensis, Convolvulus arvensis, Cynosurus cristatus, Dactylis glomerata, Festuca pratensis, Galium verum, Holcus lanatus, Leontodon hispidus, Lotus corniculatus, Poa pratensis, Plantago lanceolata, Ranunculus acris, Rhinanthus rumelicus, Rumex acetosa, Stellaria graminea, Taraxacum officinale, Trifolium pratense, T. repens.

Dominant species: Agrostis capillaris.

Formal definition: Group Leontodon autumnalis NOT Group Trisetum flavescens NOT Chamaespartium sagittale cover $>5 \%$ NOT Trifolium medium cover $>5 \%$.

Soil pH optimum: from medium acidic to slightly acidic (5.5-6.3).

Altitude range: $359-1629 \mathrm{~m}$.

Base rock: silicate.

The TWINSPAN divides these relevés into two groups which share the diagnostic species of the alliance. Irrespective of this division, the two groups relate to Cynosurion. The floristic similarity can be seen in Figure 3 where the two groups are not clearly separated but overlap to a large extent, unlike the other two alliances. The vegetation of alliance Cynosurion is used as pastures and hay-making meadows. In the dry subgroup grazing and mowing are dealt evenly, but in the wet subgroup there is observed a significant prevalence of mowing. This vegetation has the highest total cover (Figure 5), which emphasizes its high agricultural value. The "dry" Cynosurion is the only vegetation type managed at some places by an intensive grazing regime (Figure 4).

\section{Arrhenatherion elatioris Luquet 1926}

Diagnostic species: Cirsium arvense, Medicago lupulina, Poa pratensis, Silene vulgaris, Trifolium campestre, Trisetum flavescens, Vicia cracca. 


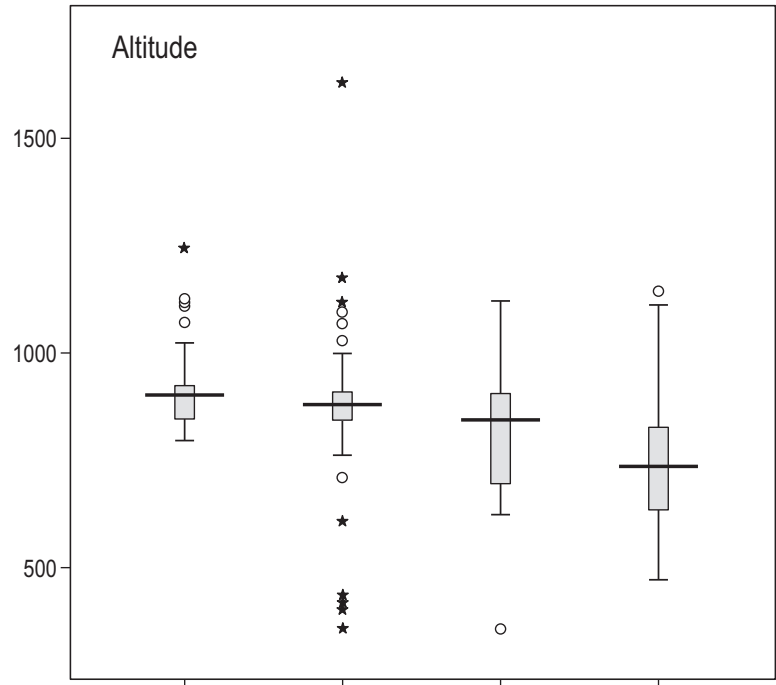

Trifolion medii dry Cynosurion wet Cynosurion Arrhenatherion

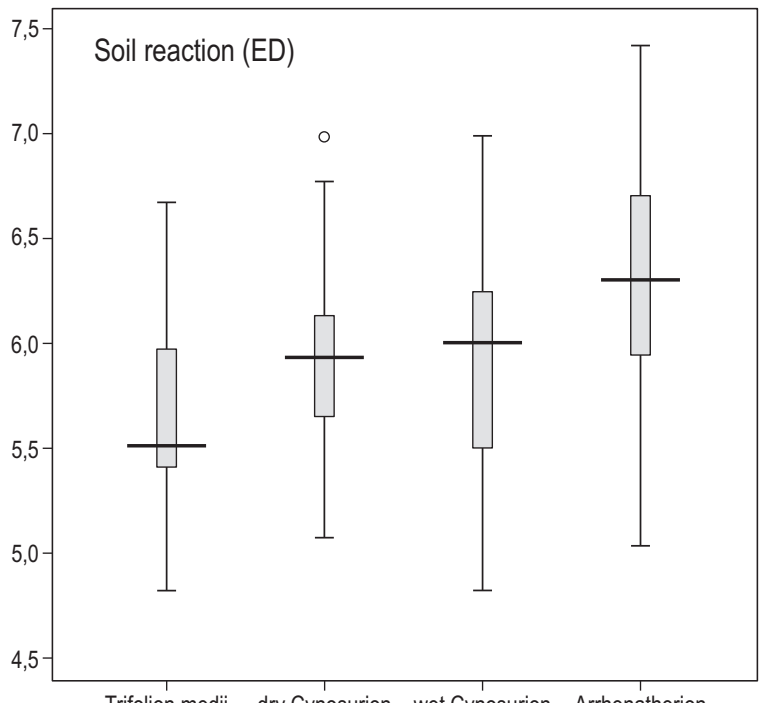

Trifolion medii dry Cynosurion wet Cynosurion Arrhenatherion

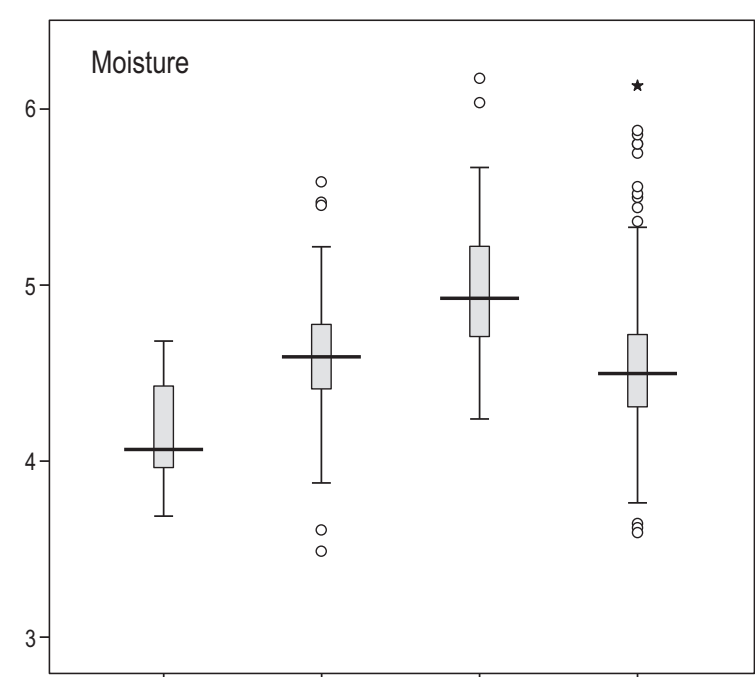

Trifolion medii dry Cynosurion wet Cynosurion Arrhenatherion

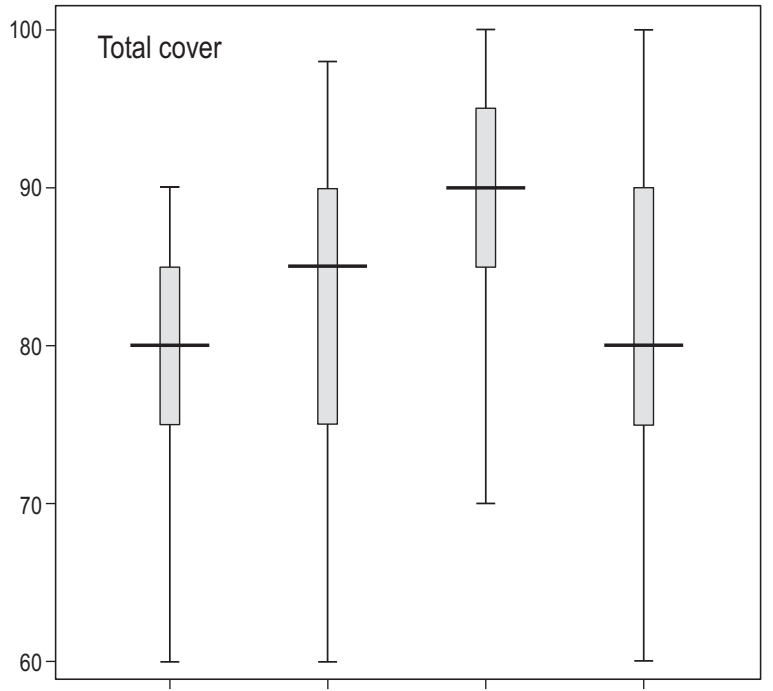

Trifolion medii dry Cynosurion wet Cynosurion Arrhenatherion
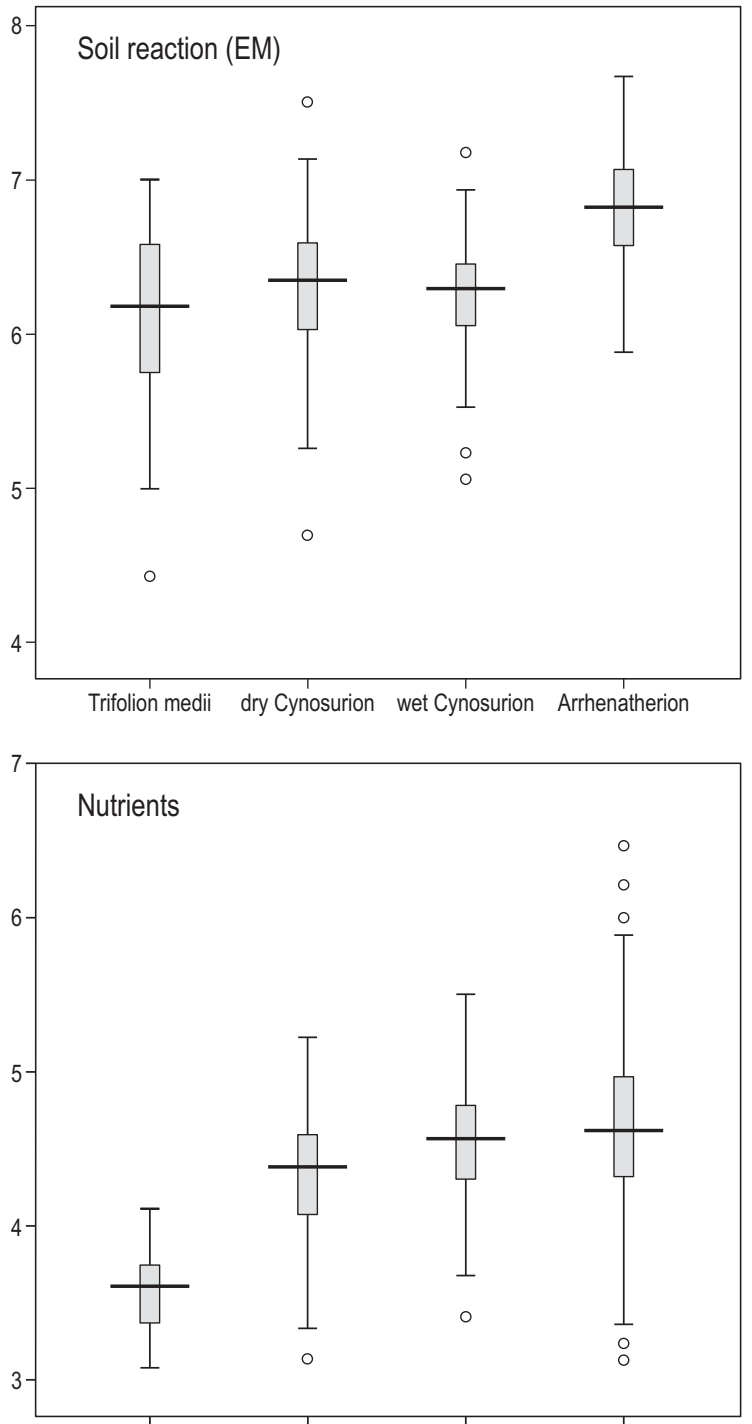

Trifolion medii dry Cynosurion wet Cynosurion Arrhenatherion 


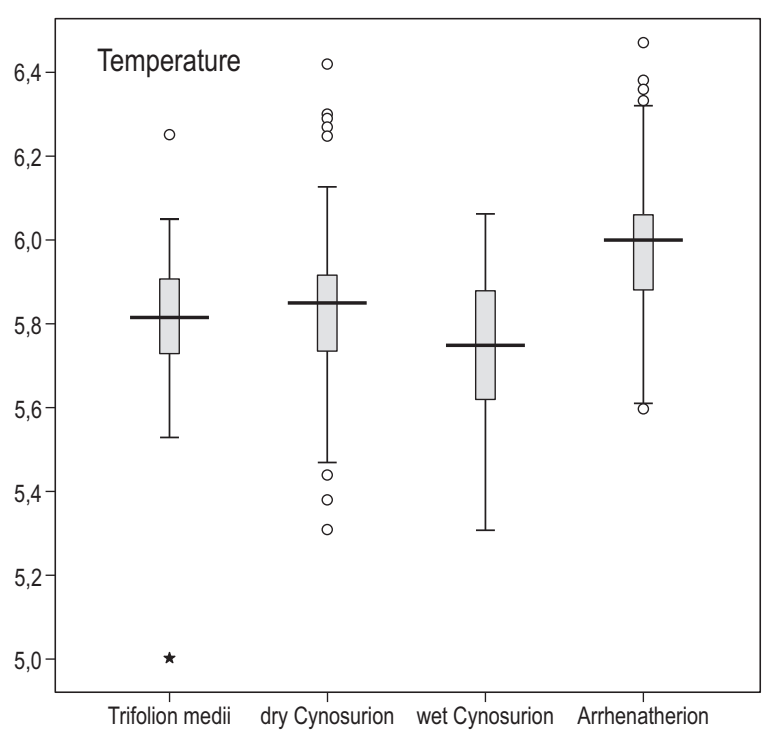

Figure 5: Box and whiskers plots of the most important variables.

Slika 5: Graf (škatla in brki) najpomembnejših spremenljivk.

Constant species: Achillea millefolium, Agrimonia eupatoria, Arrhenatherum elatius, Cirsium ligulare, Convolvulus arvensis, Dactylis glomerata, Elymus repens, Festuca pratensis, F. valesiaca, Galium verum, Lotus corniculatus, Plantago lanceolata, Poa pratensis, Taraxacum officinale, Trifolium campestre, T. pratense, $\mathcal{T}$. repens, $V$. grandiflora.

Dominant species: Arrhenatherum elatius.

Formal definition: Group Trisetum flavescens NOT Group Leontodon autumnalis NOT Group Trifolium montanum.

Soil pH optimum: from medium acidic to slightly acidic (5.9-6.7).

Altitude range: $472-1143 \mathrm{~m}$.

Base rock: in $90 \%$ of the localities is silicate and in $10 \%$ is limestone.

Communities confined to Arrhenatherion alliance are widespread in the studied area. They occupy mainly the lowest altitudes, close to settlements and agricultural fields. Some sample plots are arable lands, abandoned since 1990s, which have been recovered by the species pool of the adjacent not utilized areas. This is a reason for high fidelity coefficients for Lathyrus aphaca, Dipsacus laciniatus, Vicia pannonica, V. grandiflora, Convolvulus arvensis (Table 1). Currently these grasslands are utilized as pastures and haymaking meadows with a noticeable prevalence of mowing (Figure 4).

\section{DISCUSSION}

The mesic grasslands in the lowlands and hilly regions of western Bulgaria are classified into two distinct classes (Trifolio-Geranietea Müller 1962 and Molinio-Arrhenatheretea Tüxen 1937). It was not surprising that within the mesic grasslands the Trifolion medii alliance was also recognized, because it is pointed out by Čarni (2005) as "the most humid and rich in nutrients" representative of the class Trifolio-Geranietea. The presence of Trifolion medii within the vegetation targeted in this study reveals its ecological similarity with Arrhenatherion and Cynosurion. The fringe vegetation (like Trifolion medii) is a good example of ecotone habitats that contain a significant number of species, coming from surrounding areas (Valachovič 2004). The floristic composition of fringe communities as semi-natural grasslands largely depends on human activity, and despite the very low intensity of mowing and grazing, the management preserves the grasslands from further development into shrublands. In Bulgaria, similarly to other parts of Europe, Trifolion medii communities contain species diagnostic for other syntaxa (see Table 1). This is a reason why its position into the higher syntaxa varies significantly among different authors. Čarni (1997, 2005), Rodwell et al. (2002), Dengler (2004), Valachovič (2004) and Čarni et al. (2005) refer this alliance to Trifolio-Geranietea. According to Chytrý et al. (2007) the alliance belongs to Festuco-Brometea Br.-Bl. \& Tüxen ex Soó 1947. Some other authors classify Trifolion medii communities into Carpinion betuli Issler 1931 or Fagion Luquet 1926 and also into class Molinio-Arrhenatheretea (see Čarni et al. 2000, Valachovič 2004). The close vicinity of other semi-natural vegetation types managed as pastures or meadows for a long time supports transference of many species diagnostic for Festuco-Brometea and Molinio-Arrhenatheretea into the fringe communities where these species fall into similar ecological conditions. In the present study we obtained data showing that, floristically and ecologically, Trifolion medii is close to Cynosurion and especially to its "dry type" (Figure 3, Table 3).

According to Dierschke (1999) Cynosurion cristati is characterized by a pronounced absence of good diagnostic species. This alliance has been defined negatively in comparison with the haymaking meadows of the alliances Arrhenatherion and Polygono-Trisetion and with the pastures of the 
alliance Mesobromion (Zuidhoff et al. 1995). Horvat et al. (1974) mention that in the Balkans the Cynosurion vegetation is managed in a different way as compared to Central Europe, where it is managed as pastures and in many cases is maintained by manuring. In Bulgaria neither of the $C y$ nosurion types is enhanced by man. Nevertheless the vegetation is composed of the same species which have emphasized European or Euro-Asiatic distribution (see table 1). Only a few specific Balkan plants are included in the floral diversity. The same is obvious also for Arrhenatherion. This brings us to the conclusion that lowland mesic grasslands in the studied area do not exhibit a particular South-East European specificity. Further, this fact also allows us to use Ellenberg Indicator Values for Bulgarian mesic meadows, in spite of their origin in the Central Europe.

\section{ACKNOWLEDGEMENT}

A part of this investigation was implemented within an exchange project of the Czech and Bulgarian Academies of Sciences (2008-2010) and the long-term research plans of Masaryk University no. MSM0021622416 and GACR 526/09/H025.

We also thank the two anonymous reviewers for the helpful comments and critical remarks on a previous version of the manuscript.

\section{REFERENCES}

Apostolova, I. \& Slavova, L. 1997: Compendium of Bulgarian plant communities published during 1891-1995. "Kiril Belivanov" Inc., Sofia, $340 \mathrm{pp}$.

Apostolova, I., Meshinev, T. \& Petrova, A. 2007: Hay meadows with Trisetum flavescens in Bulgaria: syntaxonomy and implications for nature conservation. Phytologia Balcanica 13(3): 401-414.

Assyov, B. \& Petrova, A. (eds). 2006: Conspectus of the Bulgarian Vascular Flora. Distribution Maps and Floristic Elements. Ed. 3. BBF, Sofia, $453 \mathrm{pp}$.

Bărbos, M. I. 2006: Montane grasslands dominated by Agrostis capillaris and Festuca rubra in Maramureş County. I. Phytosociological analysis. Contributii Botanice 41(2): 41-52.

Barkman, J., Doing, H. \& Segal, S. 1964: Kritische Bemerkungen und Vorschläge zur quantitativen Vegetationsanalyse. Acta Botanica Neederlandica 13: 394-419.

Boşcaiu, N. 1971: Flora şi vegetaţia munților Țarcu, Godeanu şi Cernei. Acad. R. P. R. Bucharest, 494 pp. (in Romanian).

Braun-Blanquet, J. 1965. Plant sociology: The study of plant communities. (Transl. rev. and ed. By C.D. Fuller and H.S. Conard.) Hafner, London, 439 pp.

Bruelheide, H. 1995: Die Grünlandgesellschaften des Harzes und ihre Standortsbedingungen. Mit einem Beitrag zum Gliederungssystem auf der Basis von statistisch ermittelten Artengruppen. Dissertationes Botanicae 244: 1-338.

Bruelheide, H. 1997: Using formal logic to classify vegetation. Folia Geobotanica Phytotaxonomica 32: 41-46.

Bruelheide, H. 2000: A new measure of fidelity and its application to defining species groups. Journal of Vegetation Science 11: 167-178.

Čarni, A. 1997: Syntaxonomy of the Trifolio-Geranietea (saum vegetation) in Slovenia. Folia Geobotanica Phytotaxonomica 32(2): 207-219.

Čarni, A. 2005: Trifolio-Geranietea vegetations in south and southeast Europe. Acta Botanica Gallica 152(4): 483-496.

Čarni, A., Kostadinovski, M. \& Matevski, V. 2000: "Saum" (fringe) vegetation (Trifolio-Geranietea) in the Republic of Macedonia. Acta Botanica Croatica 59(1): 279-329.

Čarni, A., Franjić, J., Šilc, U. \& Škvorc, Ž. 2005: Floristical, ecological and structural diversity of vegetation of forest fringes of the Northern Croatia along a climatic gradient. Phyton 45: 287-303.

Chytrý, M. (ed.) 2007a: Vegetation of the Czech Republic. Grassland and Heathland Vegetation. Vol. 1. Academia, Prague, 526 pp.

Chytrý, M. 2007b: Project Vegetation of the Czech Republic: Preface and summary of methods. In: Chytrý, M. (ed.): Vegetation of the Czech Republic. Grassland and Heathland Vegetation. Vol. 1, pp. 35-52. Academia, Prague.

Chytrý, M., Tichý, L., Holt, J. \& Botta-Dukat, Z. 2002: Determination of diagnostic species with statistical fidelity measures. Journal of Vegetation Science 13: 79-90.

Chytrý, M. \& Otýpková, Z. 2003: Plot sizes used for phytosociological sampling of European vegetation. Journal of Vegetation Science 14: 563-570.

Chytrý M. \& Tichý L. 2003: Diagnostic, constant and dominant species of vegetation classes 
and alliances of the Czech Republic: a statistical revision. Folia Fac. Sci. Nat. Univ. Masaryk. Brun., Biol., 108:1-231.

Chytrý, M., Hoffmann, A. \& Novák, J. 2007: Dry grasslands. In: Chytrý, M. (ed.): Vegetation of the Czech Republic. Grassland and Heathland Vegetation. Vol. 1. Academia, Prague, pp. 371-470.

Delipavlov, D. \& Cheshmedzhiev, I. (eds) 2003: Key to the plants of Bulgaria. Acad. Press Agrarian Univ., Plovdiv, pp. 65-88 (in Bulgarian).

Dengler, J. 2004: Klasse Trifolio-Geranietea sanguinei T. Müller 1962 - Licht-und wärmebedürftige Saumgesellschaften und Staudenfluren magerer Standorte. In: Berg, C., Dengler, J., Abdank, A. \& Isermann, M. (eds.): Die Pflanzengesellschaften Mecklenburg-Vorpommerns und ihre Gefährdung - Textband. WeisdornVerlag Jena, pp. 362-379.

Dierschke, H. 1995: Syntaxonomical survey of Molinio-Arrhenatheretea in Central Europe. Colloques Phytosociologiques 23: 387-399.

Dierschke, H. 1997: Molinio-Arrhenatheretea (E 1). Kulturgrasland und verwandte Vegetationstypen. Teil 1: Arrhenatheretalia. Wiesen und Weiden frischer Standorte. Göttingen, 74 pp.

Dierschke, H. 1999: Short survey of Arrhenatheretalia grasslands in Germany. Annali di Botanica 57: 7-15.

Dihoru, G. 1975: The vegetal cover of the Siriu Mountain. Edit. Acad. Press, Bucharest, 216 pp. (in Romanian).

Dimitrov, M. 2001: Syntaxonomic analysis of herbaceous vegetation in the Yundola Forestry Experimental Station. In: Temniskova, D. (ed.): Sixth Natl. Conf. Bot. Univ. Sofia, Sofia pp. 263-276 (in Bulgarian).

Dimitrov, M. 2004: Floristic classification of the vegetation in the Yundola Forestry Experimental Station. PhD Thesis, Univ. of Forestry Press, Sofia (in Bulgarian, unpubl.).

Dutoit, T., Buisson, E., Roche, P. et alard, D. 2003: Land use history and botanical changes in the calcareous hillsides of Upper-Normandy (north-western France): new implications for their conservation management. Biological Conservation 115: 1-19.

Ellenberg, H. 1988: Vegetation ecology of Central Europe. Cambridge University Press, Cambridge, $731 \mathrm{pp}$.

Ellenberg, H., Weber, H., Düll, R., Wirth, W., Werner, W. \& Paulissen, D. 1992: Zeigerwerte von Pflanzen in Mitteleuropa. Ed. 2. Scripta Geobotanica 18: 1-258.

Ellmauer, T. \& Mucina, L. 1993: Mollinio-Arrhenatheretea. In: Mucina, L., Grabherr, G. \& Ellmauer, T. (eds.): Die Pflanzengesellschaften Österreichs. Teil I. Gustav Fischer Verlag, Jena, pp. 297-401.

Gandullo, R. \& Faggi, A. 2005: Interpretación sintaxonómica de los humedales del noroeste de la provincia de Neuquén, Argentina. Darwiniana 43(1-4): 10-29.

Hájková, P., Hájek, M., Blažkova, D., Kučera, T., Chytrý, M., Řezničková, M., Šumberová, K., Černy, T., Novák, J. \& Simonová, D. 2007: Meadows and mesic pastures (Molinio-Arrhenatheretea). In: Chytrý, M. (ed.): Vegetation of the Czech Republic. Grassland and Heathland. Vol. 1. Academia, Prague, pp. 165-280.

Hennekens, S. \& Schaminèe, J. H. J. 2001: TURBOVEG, a comprehensive data base management system for vegetation data. Journal of Vegetation Science 12: 589-591.

Hill, M. 1979: TWINSPAN a FORTRAN for arranging multivariate data in an ordered twoway table by classification of individuals and attributes. Cornell University, Ithaca, $45 \mathrm{pp}$.

Horvat, I., Glavač, V. \& Ellenberg, H. 1974: Vegetation Südosteuropas. G. Fisher Verl. Stuttgart, $766 \mathrm{pp}$.

ISO 10390: 1994: Soil quality - Determination of $\mathrm{pH}$.

Janišová, M. (ed.) 2007: Grassland vegetation of Slovak Republic - electronic expert system for identification of syntaxa. SAV, Bratislava, 263 pp.

Kent, M. \& Coker, P. 1992: Vegetation description and analysis. A practical approach. John Wiley \& Sons, London, 336 pp.

Kojić, M., Popović, R. \& Karadžić, B. 1998: A syntaxonomic Review of Vegetation in Serbia. Inst. za biol. istrazivanja "Siniša Stanković", Belgrade, 218 pp. (in Serbian).

Knapp, R. 1984: Sample (relevè) areas (distribution, homogeneity, size, shape) and plot-less sampling. In: Knapp, R. (ed.): Handbook of Vegetation Science 4. Junk, The Hague, pp. 101-119.

Kozhuharov, S., (ed.). 1992: Field Guide to the Vascular Plants in Bulgaria. Naouka \& Izkoustvo, Sofia, 788 pp. (in Bulgarian).

Lepš, J. \& Šmilauer, P. 2003: Multivariate Analysis of Ecological Data using CANOCO. Cambridge University Press, Cambridge, 269 pp. 
Levene, H. 1960: Robust tests for equality of variances. In: Olkin, I. et al. (eds): Contributions to Probability and Statistics: Essays in Honor of Harold Hotelling. Stanford Univ. Press, Stanford, pp. 278-292.

Lieth, H., Berlekamp, J., Fuest, S. \& Riediger, S. 1999: Climate Diagram World Atlas. CD-Series. Climate and Biosphere, Backuys Publishers, Leiden.

Lopez, G. 1978: Contribución al conocimiento fitosociológico de la Serranía de Cuenca, II. Comunidades herbáceas: vegetación de rocas y pedreras; comunidades acuáticas; prados húmedos y juncales; praderas y pastizales; malezas ruderales y arvenses. Anal. Inst. Bot. Cavanilles, 34(2): 597-702.

McDonald, J. 2008: Handbook of biological statistics. Sparky House Publishing, Baltimore, Maryland, $319 \mathrm{pp}$.

Meshinev, T., Apostolova, I., Georgiev, V., Dimitrov, V., Petrova, A. \& Veen, P. 2005: Grasslands of Bulgaria. Final report on the National Grasslands Inventory Project - Bulgaria, 2001-2004. Dragon 2003 Ltd. Publishers, Sofia, $104 \mathrm{pp}$.

Mucina, L. 1997: Conspectus of classes of European vegetation. Folia Geobotanica Phytotaxonomica 32: 117-172.

Mueller-Dombois, D. \& Ellenberg, H. 1974: Aims and Methods of Vegetation Ecology. John Wiley \& Sons, Inc., New York, 547 pp.

Oberdorfer, E. 1994: Exkursionsflora. Verlag Eugen Ulmer., Stuttgart, 1049 pp.

Otýpková Z. \& Chytrý M. 2006: Effects of plot size on the ordination of vegetation samples. Journal of Vegetation Science 17: 465-472.

Parolly, G. 2003: Towards common standards in phytosociological papers submitted to the Turkish Journal of Botany: A Letter from the Editor. Turkish Journal of Botany 27: 163-165.

Pavlov, D., Dimitrov, M. \& Malinova, D. 2006: Syntaxonomic analysis of the vegetation in landscape types in Bulgarka Nature Park. Nauka Gorata, 1: 3-29 (in Bulgarian).

Pop, I., Cristea, V. \& Hodişan, I. 2002: The Vegetation of Cluj District (a phytocoenological, ecological, bioeconomic and ecoprotective study). Contributiii Botanice, 35(2): 5-254.

Resmeriță, I. 1970: Flora, vegetation and productivity potential of the Vlădeasa massif. Acad. Press, Bucharest, 318 pp. (in Romanian).

Rodwell, J., Shaminee, J., Mucina, L., Pignatti, S., Dring, J. \& Moss, D. 2002. The diversity of
European vegetation. An overview of phytosociological alliances and their relationships to EUNIS habitats. Wageningen, $168 \mathrm{pp}$.

Sanda, V., Popescu, A. \& Barabaş, N. 1997: Syntaxonomy and characteristics of Romanian vegetation. Bacau, 366 pp. (in Romanian).

Šeffer, J., Lasák, R., Galvánek, D. \& Stanová, V. 2002: Grasslands of Slovakia. Final report on National Grassland Inventory 1998 - 2002. DAPHNE - Institute of applied Ecology, Bratislava, 56 pp.

Snowarski, M. 2002-2005: Vascular Plants of Poland photoflora - http://www.atlas-roslin.pl/. (accessed 17.02.2010).

Stančić, Z. 2008: Classification of mesic and wet grasslands in northwest Croatia. Biologia 63(6): 1089-1103.

ter Braak, C. 1994: Canonical community ordination. Part 1: Basic theory and linear methods. Ecoscience 1(2): 127-140.

ter Braak, C. \& Šmilauer, P. 2002: CANOCO Reference Manual and CanoDraw for Windows User's Guide: Software for Canonical Community Ordination (version 4.5). Microcomputer Power, Ithaca, New York, $351 \mathrm{pp}$.

Tichý, L. 2002: JUICE, software for vegetation classification. Journal of Vegetation Science 13: 451-453.

Tichý, L. \& Holt, J. 2006: JUICE program for management, analysis and classification of ecological data. Program manual. Brno, 98 pp. - http://www.sci.muni.cz/botany/juice/jc06_ man.htm (accessed 11.02.2009).

Tzonev, R., Dimitrov, M., \& Roussakova, V. 2009: Syntaxa according to the Braun-Blanquet approach in Bulgaria. Phytologia Balcanica 15(2): 209-233.

Valachovič, M. 2004: Syntaxonomy of the fringe vegetation in Slovakia in relation to surrounding areas - preliminary classification. Hacquetia 3(1): 9-25.

van der Maarel, E. 1979: Transformation of coverabundance values in phytosociology and its effect on community similarity. Vegetatio 39: 97-114.

van der Maarel, E. 2005: Vegetation ecology - an overview. In: van der Maarel, E. (ed.): Vegetation ecology. Blackwell Publ., Padstow, Cornwall, pp. 1-51.

Veen, P., Jefferson, R., de Smidt \& van der Straaten, J. (eds) 2009: Grasslands in Europe of high nature value. KNNV Publishing, Zeist, The Netherlands, 319 pp. 
Velev, St. 2002: Climatic regioning. In: Kopralev, I. (ed.): Geography of Bulgaria. ForCom, pp. 155-156.

Westhoff, V. \& van der Maarel, E. 1973: The Braun-Blanquet approach. 2nd Ed. In: Whittaker, R. (ed.): Classification of plant communities. Junk, The Hague, pp. 287-399.

Whittaker, R. 1973: Direct gradient analysis: Techniques. In: Whittaker, R. (ed.): Handbook of Vegetation Science 5. Junk, The Hague, pp. 7-32.
Zelnik, I. 2007: New grassland association TrisetoCentaureetum macroptili ass. nova in Slovenia. - Hacquetia 6(1): 77-89.

Zuidhoff, C., Rodwell, S. \& Schaminée, H.J. 1995: The Cynosurion cristati Tx. 1947 of central, southern and western Europe: a tentative overview, based on the analysis of individual relevés. Ann. Bot. 53: 25-47.

Received 1. 4. 2010

Revision received 6. 8. 2010

Accepted 12. 8. 2010

Table 1: Synoptic table of the studied vegetation units.

The species are represented by two indicators: Fidelity measure, expressed by the Phi-coefficient (Chytrý \& al. 2002) and Constancy, expressed in percentages.

Tabela 1: Sinoptična tabela proučevanih vegetacijskih tipov.

Vrste so predstavljene z dvema indikatorjema: mero naveznosti, kot Fi koeficient (Chytrý \& al. 2002) in prisotnostjo v odstotkih.

\begin{tabular}{|c|c|c|c|c|c|c|c|c|c|}
\hline \multirow{4}{*}{$\begin{array}{l}\text { Biogeographical } \\
\text { affiliation } \\
\text { of the species }\end{array}$} & \multirow{4}{*}{$\begin{array}{l}\text { Syntaxa } \\
\text { Number of relevés } \\
\text { Fidelity / Constnacy }\end{array}$} & \multirow{2}{*}{\multicolumn{2}{|c|}{ Trifolion medii }} & \multicolumn{4}{|c|}{ Cynosurion cristati } & \multirow{2}{*}{\multicolumn{2}{|c|}{$\begin{array}{l}\text { Arrhenatherion } \\
\text { elatioris }\end{array}$}} \\
\hline & & & & \multirow{2}{*}{\multicolumn{2}{|c|}{$\begin{array}{c}\text { dry type } \\
139\end{array}$}} & \multirow{2}{*}{\multicolumn{2}{|c|}{$\begin{array}{c}\text { wet type } \\
66\end{array}$}} & & \\
\hline & & \multicolumn{2}{|c|}{30} & & & & & \multicolumn{2}{|c|}{298} \\
\hline & & Phi & $\%$ & Phi & $\%$ & Phi & $\%$ & Phi & $\%$ \\
\hline & Trifolion medii & & & & & & & & \\
\hline Eur-subMed & Trifolium montanum & 47,5 & 50 & - & 14 & - & 5 & - & 4 \\
\hline Euras & Trifolium medium & 39,6 & 27 & - & 4 & - & 2 & - & 1 \\
\hline \multirow[t]{2}{*}{ Euras } & Centaurea jacea & 36,8 & 47 & - & 12 & - & 18 & - & 6 \\
\hline & Trifolio-Geranietea & & & & & & & & \\
\hline Epralp & Thesium bavarum & 43,9 & 37 & - & 6 & - & 2 & - & 4 \\
\hline Eur-subMed & Geranium sanguineum & 29,4 & 13 & - & . & - & 2 & - & . \\
\hline Med-subMed & Dorycnium herbaceum & 27,8 & 23 & - & 11 & - & 2 & - & 2 \\
\hline EEur & Ferulago sylvatica & 27,7 & 10 & - & . & - & . & - & . \\
\hline \multirow[t]{2}{*}{ subMed-Eur } & Lathyrus niger & 27,2 & 13 & - & 3 & - & . & - & . \\
\hline & Festuco-Brometea & & & & & & & & \\
\hline subMed & Helianthemum nummularium & 54,6 & 43 & - & 2 & - & 3 & - & 1 \\
\hline Ealp & Hieracium hoppeanum & 50,1 & 43 & - & 9 & - & . & - & 2 \\
\hline Med-Eur & Danthonia alpina & 46,1 & 63 & - & 15 & 3,5 & 30 & - & 2 \\
\hline Euras & Hypochaeris maculata & 41 & 23 & - & . & - & 2 & - & . \\
\hline Euras & Inula salicina & 38,5 & 27 & - & 6 & - & . & - & 1 \\
\hline Euras & Briza media & 37,6 & 73 & - & 39 & 3,1 & 44 & - & 9 \\
\hline subMed & Asperula cynanchica & 35,7 & 23 & - & 3 & - & 2 & - & 1 \\
\hline Balc & Dianthus cruentus & 35,5 & 20 & - & 3 & - & . & - & . \\
\hline Eur & Veronica austriaca & 35,5 & 17 & - & . & - & . & - & 1 \\
\hline Euras & Thymus pulegioides & 33,3 & 30 & - & 12 & - & 3 & - & 2 \\
\hline Eur & Thymus glabrescens & 32,6 & 33 & - & 12 & - & 2 & - & 9 \\
\hline subMed & Euphorbia cyparissias & 32,5 & 40 & 5 & 22 & - & 3 & - & 8 \\
\hline Euras & Koeleria macrantha & 28,2 & 20 & - & 2 & - & 3 & - & 4 \\
\hline Pont-Med & Chrysopogon gryllus & 27,1 & 13 & - & 1 & - & 2 & - & 1 \\
\hline
\end{tabular}




\begin{tabular}{|c|c|c|c|c|c|c|c|c|c|}
\hline \multirow{2}{*}{$\begin{array}{l}\text { Biogeogr. affiliation } \\
\text { Eur }\end{array}$} & \multirow{2}{*}{$\begin{array}{l}\text { Number of relevés } \\
\text { Prunella grandiflora }\end{array}$} & \multicolumn{2}{|c|}{30} & \multicolumn{2}{|c|}{139} & \multicolumn{2}{|c|}{66} & \multicolumn{2}{|c|}{298} \\
\hline & & 24,6 & 10 & - & . & - & 2 & - & . \\
\hline & Cynosurion dry type & & & & & & & & \\
\hline Euras & Agrostis capillaris & 26,5 & 83 & 42,8 & 97 & - & 59 & - & 4 \\
\hline Euras & Cichorium intybus & - & 13 & 32,8 & 57 & - & 12 & - & 40 \\
\hline Eur-subatl & Leontodon autumnalis & - & 10 & 32,7 & 50 & - & 33 & - & 9 \\
\hline \multirow[t]{2}{*}{ Euras } & Phleum pratense & - & 13 & 23,5 & 38 & - & 26 & - & 8 \\
\hline & Cynosurion wet type & & & & & & & & \\
\hline satl-subMed & Cynosurus cristatus & - & 47 & 18,6 & 75 & 41 & 94 & - & 20 \\
\hline Euras & Anthoxanthum odoratum & - & 60 & 14,2 & 68 & 31,7 & 83 & - & 13 \\
\hline Euras & Trifolium repens & - & 33 & - & 64 & 24,2 & 79 & - & 56 \\
\hline \multirow[t]{2}{*}{ satl-subMed } & Holcus lanatus & - & 37 & 16,7 & 53 & 23,7 & 59 & - & 7 \\
\hline & Arrhenatherion & & & & & & & & \\
\hline Euras & Medicago lupulina & - & . & - & 10 & - & 17 & 43,4 & 48 \\
\hline Euras & Vicia cracca & - & 17 & - & 22 & - & 17 & 38,2 & 58 \\
\hline Euras & Silene vulgaris & - & . & - & 1 & - & 2 & 32 & 17 \\
\hline Euras & Poa pratensis & - & 40 & - & 59 & - & 68 & 29,6 & 89 \\
\hline preAlp-subMed & Trisetum flavescens & - & 17 & - & 16 & - & 14 & 27,8 & 42 \\
\hline subMed-satl & Trifolium campestre & - & 30 & - & 23 & - & 29 & 25 & 55 \\
\hline Euras & Cirsium arvense & - & 3 & - & 14 & - & 9 & 25 & 29 \\
\hline Euras & Galium album & - & 3 & - & 11 & - & 5 & 24,3 & 23 \\
\hline satl-subMed & Arrhenatherum elatius & - & 20 & - & 47 & - & 38 & 23,9 & 62 \\
\hline \multirow[t]{2}{*}{ Euras } & Dactylis glomerata & - & 23 & - & 65 & - & 58 & 21,7 & 73 \\
\hline & Molinio-Arrhenatheretea & & & & & & & & \\
\hline Euras & Rumex acetosella & 38,9 & 37 & 2,6 & 15 & - & 2 & - & 1 \\
\hline Eur & Potentilla alba & 35,5 & 23 & - & 1 & - & 5 & - & . \\
\hline Euras & Avenula pubescens & 33,4 & 23 & - & 3 & - & 3 & - & 2 \\
\hline Euras & Festuca rubra & 31 & 43 & 0,4 & 22 & - & 17 & - & 4 \\
\hline Euras & Luzula campestris & 29,7 & 27 & - & 6 & - & 9 & - & 1 \\
\hline Euras & Deschampsia caespitosa & - & 3 & 29,4 & 39 & - & 29 & - & 5 \\
\hline Euras & Lotus corniculatus & - & 53 & 20,7 & 80 & - & 61 & - & 56 \\
\hline Eur & Festuca nigrescens & - & 57 & 10,2 & 45 & - & 20 & - & 23 \\
\hline Eur & Cirsium canum & - & . & - & 9 & 56,5 & 59 & - & 12 \\
\hline subMed-Med & Trifolium patens & - & 3 & - & 6 & 51,3 & 47 & - & 4 \\
\hline Eur & Centaurea phrygia & - & 10 & - & 11 & 48,2 & 50 & - & 1 \\
\hline Euras & Alopecurus pratensis & - & 7 & - & 42 & 45,3 & 80 & - & 38 \\
\hline Euras & Carex hirta & - & 7 & - & 10 & 39,8 & 42 & - & 8 \\
\hline Euras & Prunella vulgaris & - & 13 & 6,9 & 34 & 39,3 & 59 & - & 7 \\
\hline Euras & Lathyrus pratensis & - & 3 & - & 30 & 38,9 & 62 & - & 28 \\
\hline Euras & Lysimachia nummularia & - & . & - & 3 & 34,7 & 21 & - & 2 \\
\hline Euras & Rumex acetosa & 24,7 & 73 & - & 40 & 32,8 & 80 & - & 14 \\
\hline Euras & Festuca pratensis & - & 37 & - & 58 & 32,1 & 91 & - & 72 \\
\hline preAlp & Carum carvi & - & 20 & - & 14 & 29,6 & 44 & - & 12 \\
\hline Euras & Ranunculus acris & - & 33 & - & 58 & 28,7 & 76 & - & 36 \\
\hline EsubMed & Leucanthemum vulgare & - & 47 & - & 34 & 25,8 & 65 & - & 27 \\
\hline Euras & Cerastium holosteoides & - & 43 & - & 42 & 24,7 & 67 & - & 30 \\
\hline Euras & Stellaria graminea & - & 70 & - & 55 & 23,5 & 82 & - & 41 \\
\hline subMed-satl & Colchicum autumnale & - & 7 & - & 4 & 23,2 & 20 & - & 4 \\
\hline EsubMed & Rhinanthus rumelicus & - & 50 & - & 53 & 23,1 & 74 & - & 41 \\
\hline Euras & Carex pallescens & - & . & - & 1 & 19,5 & 6 & - & . \\
\hline Euras & Mentha longifolia & - & . & - & 4 & - & 5 & 23,4 & 15 \\
\hline Euras & Vicia tetrasperma & - & 10 & - & 26 & - & 15 & 21,8 & 38 \\
\hline Euras & Poa trivialis & - & . & - & 1 & - & 6 & 19,7 & 12 \\
\hline & Other species & & & & & & & & \\
\hline
\end{tabular}




\begin{tabular}{|c|c|c|c|c|c|c|c|c|c|}
\hline \multirow{2}{*}{$\frac{\text { Biogeogr. affiliation }}{\text { subatl-subMed }}$} & \multirow{2}{*}{$\begin{array}{l}\text { Number of relevés } \\
\text { Chamaespartium sagittale }\end{array}$} & \multicolumn{2}{|c|}{30} & \multicolumn{2}{|c|}{139} & \multicolumn{2}{|c|}{66} & \multicolumn{2}{|c|}{298} \\
\hline & & 79,5 & 73 & - & 1 & - & 2 & - & 1 \\
\hline & Orobanche sp. & 42,1 & 23 & - & 1 & - & . & - & . \\
\hline Alp & Plantago subulata & 32,2 & 13 & - & . & - & . & - & . \\
\hline subatl-subMed & Hypochaeris radicata & 28,6 & 23 & - & 9 & - & 3 & - & 1 \\
\hline Balc & Armeria rumelica & 27,7 & 10 & - & . & - & . & - & . \\
\hline Eur & Silene otites & 27,7 & 10 & - & . & - & . & - & . \\
\hline Euras & Cuscuta europaea & 26,2 & 10 & - & 1 & - & . & - & . \\
\hline Euras & Poa compressa & - & 7 & 31,4 & 29 & - & 3 & - & 8 \\
\hline Euras & Rosa canina & - & 30 & 25 & 46 & - & 14 & - & 18 \\
\hline subMed-subatl & Centaurium erythraea & - & 3 & 21,9 & 13 & - & 3 & - & . \\
\hline subatl-subMed & Dianthus armeria & - & . & 21,3 & 6 & - & . & - & 1 \\
\hline Euras & Hypericum perforatum & - & 47 & 21 & 47 & - & 8 & - & 21 \\
\hline EsubMed & Hieracium praealtum & - & 13 & 19,1 & 27 & - & 9 & - & 12 \\
\hline Euras & Bromus arvensis & - & . & - & 13 & 43,1 & 58 & - & 30 \\
\hline Euras & Vicia angustifolia & - & 3 & - & 9 & 27,3 & 30 & - & 13 \\
\hline Euras & Poa sylvicola & - & . & - & . & 26,9 & 12 & - & 2 \\
\hline Euras & Filipendula vulgaris & 25,7 & 57 & - & 22 & 26,8 & 58 & - & 5 \\
\hline Euras & Festuca rupicola & - & . & - & . & 23,5 & 11 & - & 3 \\
\hline Eur-Med & Silene italica & - & . & - & . & 21,5 & 6 & - & . \\
\hline subatl-subMed & Ornithogalum umbellatum & - & 7 & - & 1 & 21,3 & 14 & - & 1 \\
\hline Euras & Linum catharicum & - & 7 & - & . & 20,6 & 14 & - & 2 \\
\hline subMed-pralp & Allium carinatum & - & . & - & 6 & 20,1 & 12 & - & 1 \\
\hline Eur & Gagea pratensis & - & . & - & 1 & 19,5 & 6 & - & . \\
\hline EsubMed & Allium flavum & - & 3 & - & 1 & 18,8 & 9 & - & . \\
\hline subMed-subatl & Geranium dissectum & - & 3 & - & 1 & - & 3 & 42,5 & 31 \\
\hline Eur & Salvia nemorosa & - & 3 & - & 1 & - & 5 & 40,3 & 31 \\
\hline EsubMed & Vicia grandiflora & - & 20 & - & 25 & - & 20 & 35,6 & 60 \\
\hline subMed & Tragopogon dubius & - & . & - & 5 & - & 2 & 31,9 & 21 \\
\hline Med-subMed & Lathyrus aphaca & - & . & - & . & - & 2 & 30,8 & 14 \\
\hline EsubMed-Med & Vicia pannonica & - & . & - & . & - & 2 & 30,4 & 14 \\
\hline Euras & Convolvulus arvensis & - & 10 & - & 58 & - & 52 & 29,9 & 74 \\
\hline EMed & Dipsacus laciniatus & - & . & - & 8 & - & 3 & 29,5 & 22 \\
\hline Eur & Onobrychis arenaria & - & . & - & 1 & - & 6 & 28,9 & 19 \\
\hline Med-subMed & Xeranthemum anпuит & - & . & - & . & - & 2 & 28,1 & 12 \\
\hline Euras & Elymus repens & - & 10 & - & 31 & - & 33 & 27,4 & 54 \\
\hline Euras & Myosotis arvensis & - & 3 & - & 5 & - & 11 & 26,8 & 26 \\
\hline Euras & Cirsium vulgare & - & . & - & 4 & - & 2 & 26,5 & 15 \\
\hline Euras & Echium vulgare & - & . & - & 1 & - & . & 26,4 & 11 \\
\hline subMed-Med & Lathyrus nissolia & - & . & - & 7 & - & 5 & 25,5 & 20 \\
\hline EsubMed & Vicia villosa & - & 3 & - & 2 & - & 5 & 23,7 & 17 \\
\hline subMed & Dasypyrum villosum & - & . & - & . & - & . & 23,2 & 7 \\
\hline subMed & Bromus sterilis & - & . & - & 4 & - & 3 & 22,9 & 14 \\
\hline Eur & Coronilla varia & - & 7 & - & 4 & - & 5 & 22,7 & 20 \\
\hline Euras & Astragalus glycyphyllos & - & 3 & - & 3 & - & . & 21,3 & 12 \\
\hline Euras & Chamomilla recutita & - & . & - & 2 & - & . & 21,3 & 9 \\
\hline Eur & Cirsium ligulare & - & 13 & - & 45 & - & 29 & 21,1 & 52 \\
\hline Euras & Chondrilla juncea & - & . & - & 4 & - & . & 20 & 9 \\
\hline subMed-Med & Galium aparine & - & . & - & . & - & 3 & 19,8 & 9 \\
\hline Euras & Alopecurus myosuroides & - & . & - & . & - & . & 19,6 & 5 \\
\hline Euras & Arctium lappa & - & . & - & . & - & . & 19,6 & 5 \\
\hline Euras & Medicago falcata & - & . & - & 1 & - & 5 & 19,3 & 10 \\
\hline Euras & Artemisia vulgaris & - & 3 & - & . & - & 2 & 19,3 & 10 \\
\hline Eur & Cardaria draba & - & . & - & . & - & . & 18,9 & 5 \\
\hline
\end{tabular}




\begin{tabular}{|c|c|c|c|c|c|c|c|c|c|}
\hline Biogeogr. affiliation & Number of relevés & & & & & & & & \\
\hline subMed-subatl & Clematis vitalba & - & . & - & . & - & . & 18,9 & 5 \\
\hline EsubMed & Melissa officinalis & - & . & - & . & - & . & 18,9 & 5 \\
\hline Euras & Taeniatherum caput-medusae & - & . & - & 2 & - & . & 18,9 & 7 \\
\hline Euras & Euphorbia esula & - & . & - & 2 & - & . & 18,3 & 7 \\
\hline Euras & Erodium cicutarium & - & . & - & . & - & . & 18,2 & 4 \\
\hline Med-subMed & Medicago minima & - & . & - & . & - & . & 18,2 & 4 \\
\hline Euras & Tanacetum vulgare & - & . & - & 1 & - & . & 18,1 & 5 \\
\hline subatl-subMed & Trifolium striatum & - & 7 & - & 5 & - & 27 & 13,3 & 24 \\
\hline
\end{tabular}

Table 2: Summarized statistical components of the obtained vegetation units.

Tabela 2: Statističen povzetek lastnosti vegetacijskih enot.

\begin{tabular}{|c|c|c|c|c|c|c|c|}
\hline \multirow[b]{2}{*}{ Vegetation unit } & \multicolumn{7}{|c|}{ Statistical components } \\
\hline & 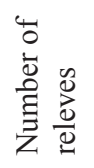 & 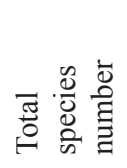 & 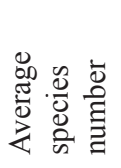 & 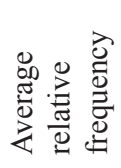 & 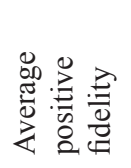 & 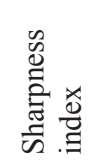 & 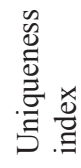 \\
\hline Trifolion medii & 30 & 220 & 39 & 17,64 & 34,43 & 24,08 & 38,8 \\
\hline Cynosurion wet type & 66 & 286 & 42 & 14,67 & 27,44 & 12,77 & 42 \\
\hline Arrhenatherion & 298 & 411 & 36 & 8,68 & 24,4 & 9,14 & 35,7 \\
\hline Cynosurion dry type & 139 & 316 & 37 & 11,79 & 18,6 & 3,78 & 37,3 \\
\hline
\end{tabular}

Table 3: Multiple comparison of environmental factors among studied alliances in one-way ANOVA with Bonferroni and Tamhane post-hoc tests. Only variables different at significance level $\mathrm{P}<0.05$ are presented. Abbreviations: $\mathrm{A}=$ altitude, $\mathrm{Cov}=$ total cover, Cont $=$ continentality, $\mathrm{L}=$ light, $\mathrm{M}=$ moisture, $\mathrm{N}=$ nutrients, $\mathrm{pH}-\mathrm{ED}=$ empirical obtained soil reaction, $\mathrm{pH}-\mathrm{Ell}=$ soil reaction obtained using EIV, rich $=$ species richness, $\mathrm{T}=$ temperature.

Tabela 3: Primerjava rastiščnih faktorjev med obravnavanimi zvezami z enosmerno analizo variance (ANOVA) z post-hoc testi (Bonferroni in Tamhane). Prikazane so samo spremenljivke, ki so statistično signifikantne $(\mathrm{P}<0.05)$. Okrajšave: $\mathrm{A}=$ višina, $\mathrm{Cov}=$ skupna pokrovnost, $\mathrm{Cont}=$ kontinentalnost, $\mathrm{L}=$ svetloba, $\mathrm{M}=$ vlažnost, $\mathrm{N}=$ hranila, $\mathrm{pH}-\mathrm{ED}=$ izmerjena rekacija tal, $\mathrm{pH}$-Ell = rekacij tal z EIV, rich = število vrst, $\mathrm{T}=$ temperatura.

\begin{tabular}{|c|c|c|}
\hline Dry Cynosurion & Wet Cynosurion & Arrhenatherion \\
\hline Cont; M; N; pH-ED & A; Cov; L; Cont; M; N; pH-Ell; pH-ED & A; Cov; L; T; M; N; pH-Ell; pH-ED \\
\hline \multirow[t]{2}{*}{ Dry Cynosurion } & Cov; L; T; M; rich & A; L; T; Cont; N; pH-Ell; pH-ED \\
\hline & Wet Cynosurion & A; Cov; L; T; Cont; M; pH-Ell; pH-ED; rich \\
\hline
\end{tabular}

